\title{
The Justiciability of Municipal Preemption Challenges to State Law
}

\author{
Alexander Willscher $\dagger$
}

Imagine the following scenario: the City of Abilene, Texas, plans to construct a broadband cable network that will provide its citizens with high speed internet access. However, Texas law prohibits municipalities from providing telecommunications services. ' Undaunted, Abilene's city planners file a federal complaint alleging that the Telecommunications Act of 1996, which prohibits states from denying any entity the right to provide telecommunications service, preempts the state law. ${ }^{2}$ Among the issues that a federal court must address in such a suit are (a) whether Congress has the authority to grant the municipality a cause of action to sue its parent state, and if so, (b) whether Congress, in fact, has granted such a cause of action. Currently, lower federal courts disagree about how to resolve these questions. ${ }^{3}$

The most fundamental disagreement is about whether municipalities have a cause of action under federal law to sue. Some circuits argue that municipalities are political subdivisions of the state, which the state creates to help it administer its laws. As creator, the state may modify or withdraw all municipal powers, change municipal boundaries, or repeal the municipality's corporate charter. Since the state delegates to municipalities all of their authority, municipalities lack any independent authority with which to sue the state. ${ }^{4}$

$\dagger$ B.A. 1996, Dartmouth College; J.D. Candidate 2000, The University of Chicago.

See Public Utility Regulatory Act of 1995, Tex Utilities Code Ann \$ 54.202 (Vernon 1998).

2 Telecommunications Act of 1996, 47 USC $\$ 253$ (a) (Supp 1997) ("No State or local statute or regulation, or other State or local legal requirement, may prohibit or have the effect of prohibiting the ability of any entity to provide any interstate or intrastate telecommunications service."). The FCC eventually heard this dispute and ruled that it lacked the authority to preempt state law, and that since the City of Abilene is not an entity separate from the State of Texas, the city cannot sue the state. See In re Public Utility Commission of Texas, 13 FCC Rcd 3460, 3544 (1997).

Note that the Eleventh Amendment, which generally prohibits suits against states in federal courts, does not prohibit municipal suits because the Eleventh Amendment does not prevent federal courts from granting prospective injunctive relief to prevent a continuing violation of federal law. See Green v Mansour, 474 US 64, 68 (1985), citing Ex parte Young, 209 US 123, 155-56,159 (1908). See also Seminole Tribe of Florida v Florida, 517 US 44, 73 (1996); Papasan $v$ Allain, 478 US 265, 277-78 (1986). Such a requirement is intended to maintain the balance between allowing the "federal courts to vindicate federal rights and hold state officials responsible to 'the supreme authority of the United States," Pennhurst State School and Hospital v Halderman, 465 US 89, 105 (1984), quoting Young, 209 US at 160, and upsetting the delicate balance of federal and state interests that is at the heart of the Eleventh Amendment.

- See cases cited in note 28 . 
Other circuits have held that municipalities may sue their parent state to enforce federal law. ${ }^{5}$ The basic argument is that occasionally municipalities are the only parties affected by a state action that violates federal law. If municipalities cannot challenge preempted state legislation, such legislation often will go unchecked even though expressly prohibited by federal law.

The narrower question of justiciability has implications for the larger debate about the balance of power between the states and the federal government. A congressional grant of authority that enables municipalities to sue their parent states would impede the states' autonomy in administering their own governments. Municipalities that previously were beholden to the states for all their power suddenly would have an independent source of power bestowed upon them by the federal government.

This Comment offers a new way to approach the question of whether municipalities may challenge a perceived conflict between state and federal law. It suggests that the justiciability of municipal suits is best understood as a question of state sovereignty. First, while the law is not entirely clear, Congress may lack the constitutional authority to grant municipalities a cause of action to challenge state law because such suits would interfere with states' sovereignty. Second, even if such a federal cause of action would be constitutional, widely used principles of statutory interpretation suggest that federal courts should not recognize a cause of action in the absence of the clearest of statements from Congress. In addition to bringing the municipality cause of action issue into a coherent normative framework, this new analysis explains the old Supreme Court rule that municipal suits against their parent states are not justiciable.

Part I discusses the Supreme Court's confusing early decisions on this issue and the current disagreement about the meaning of these precedents. This Part adds clarity to the debate by explaining that the key issue is not whether municipalities have standing to sue, but whether they have a cause of action to sue.

Parts II and III form the heart of the analysis. Part II shows why Congress may lack the constitutional authority to grant municipalities a cause of action against their parent states. Part III argues that in light of Congress's questionable authority, as well as an absence of any clear congressional statement in these cases, federal courts should deny justiciability to municipal preemption challenges.

See cases cited in note 16.

See note 7 . 


\section{COURT DECISIONS ON THE JUSTICIABILITY OF MUNICIPAL CHALLENGES TO STATE LAW}

A. Foundations of the Doctrine

In a series of cases at the beginning of the twentieth century, the Supreme Court held that municipalities may not sue their parent states for constitutional violations. However, the meaning of these cases has caused much confusion for modern courts. In particular, modern courts disagree whether the earlier cases held that municipalities lack standing or a cause of action to sue.

In Hunter $v$ City of Pittsburgh, ${ }^{8}$ the Supreme Court sustained Pennsylvania's decision to merge the city of Allegheny into the city of Pittsburgh, despite the Allegheny City Council's claims that the merger violated its citizens' rights under the Contract Clause" and the Fourteenth Amendment. ${ }^{10}$ The Court dismissed the suit, stating emphatically:

Municipal corporations are political subdivisions of the State, created as convenient agencies for exercising such of the governmental powers of the State as may be entrusted to them.... The State, therefore, at its pleasure may modify or withdraw all such powers ... expand or contract the territorial area, unite the whole or a part of it with another municipality, repeal the charter and destroy the corporation.... In all these respects the State is supreme, and its legislative body, conforming its action to the state constitution, may do as it will, unrestrained by any provision of the Constitution of the United States."

The Court expanded on this logic in City of Trenton $v$ New Jersey. ${ }^{12}$ In that case, the city of Trenton sued New Jersey arguing that a state law, which limited the amount of water that municipalities could divert from the Delaware River, violated its citizens' rights under the

'See Coleman v Miller, 307 US 433, 441 (1939) ("Being but creatures of the State, municipal corporations have no standing to invoke the contract clause or the provisions of the Fourteenth Amendment of the Constitution in opposition to the will of their creator."); Williams v Mayor and City Council of Baltimore, 289 US 36, 40 (1933) (holding that Baltimore could not sue to challenge the validity of a state law which exempted a railroad from local taxation); City of Newark v New Jersey, 262 US 192 (1923); City of Trenton v New Jersey, 262 US 182, 186-88 (1923); Hunter $v$ City of Pittsburgh, 207 US 161 (1907).

207 US 161 (1907).

- US Const Art I, \& 10, cl 1 . The Contract Clause states: "No State shall ... pass any ... Law impairing the Obligation of Contracts."

${ }^{1}$ The city claimed that the merger deprived its citizens of their property without due process of law by subjecting them to Pittsburgh's higher taxes and violated the contract between the citizens and the city that their tax dollars would be used only for city purposes. See Hunter, 207 US at 176-77.

"Id at 178-79.

$" 262$ US $182(1923)$. 
Contract Clause and the Fourteenth Amendment." The Supreme Court held that the city, as a mere "creature of the state," had no grounds on which to sue:

A municipal corporation is simply a political subdivision of the State, and exists by virtue of the exercise of the power of the State through its legislative department. The legislature could at any time terminate the existence of the corporation itself, and provide other and different means for the government of the district comprised within the limits of the former city. The city is the creature of the State. ${ }^{14}$

The Court concluded that since the state alone had the authority to grant a city its powers, the city lacked independent powers with which to bring the lawsuit:

The power of the State, unrestrained by the contract clause or the Fourteenth Amendment, over the rights and property of cities held and used for 'governmental purposes' cannot be questioned. ... This court has never held that these subdivisions may invoke such restraints upon the power of the State. ${ }^{15}$

At first glance, the Supreme Court's jurisprudence weighs heavily against permitting municipalities to sue their parent states for violations of federal law. However, it is not clear whether the Supreme Court refused to hear those cases because the municipalities lacked standing or because they lacked a cause of action to sue.

\section{B. Rogers and Its Successors: An Unsettled Question Emerges}

Some federal courts have read Hunter and Trenton narrowly, refusing to extend their holdings beyond municipal claims brought under the Fourteenth Amendment and the Contract Clause. ${ }^{16}$ The most

${ }^{13}$ Before the law came into effect, Trenton had purchased its waterworks from a private corporation to which the state had granted contractual rights to take unlimited amounts of river water. The city argued the state law offended the Constitution on two grounds: (1) the act violated the Contract Clause; and (2) the act took property owned by the city in its private capacity without just compensation or due process of law, in violation of the Fourteenth Amendment. Id at $183-84$.

"Id at 189-90.

1s Id at 188. See also Williams, 289 US at 40, in which the Supreme Court, refusing to hear the city of Baltimore's preemption challenge to a Maryland statute, stated: "A municipal corporation, created by a state for the better ordering of government, has no privileges or immunities under the Federal Constitution which it may invoke in opposition to the will of its creator." Therefore, the Court concluded: "[T] he respondents [are] without standing to invoke the protection of the Federal Constitution." Id at 47. While the Williams Court spoke in terms of the "standing" of municipalities to sue, it was actually talking about whether municipalities have a cause of action to sue. This point will be explained more fully in Part I.C.

${ }^{16}$ See Branson School District RE-82 v Romer, 161 F3d 619, 628-30 (10th Cir 1998) (holding that Colorado school districts' status as political subdivisions did not deprive them of ability to 
important of these later cases is Rogers $v$ Brockette, ${ }^{17}$ in which the Fifth Circuit refused to extend the rule against municipal suits to claims based on the Supremacy Clause. ${ }^{18}$ In Rogers, a Texas school district sued the state, challenging the constitutionality of a Texas statute that required school districts to participate in a federally subsidized breakfast program. ${ }^{19}$ In its challenge, the school district claimed that the Texas statute (which required participation) conflicted with, and therefore was preempted by, a federal statute (which the plaintiff alleged gave school districts the right to refuse to participate), under the Supremacy Clause of the Constitution. ${ }^{20}$

The Rogers court held that despite the Supreme Court's prior holdings barring suits against states, the school district could bring the suit. The court drew a distinction between the question of whether a municipality has standing to sue and whether it has a cause of action:

We think [the Hunter/Trenton line of cases] are substantive interpretations of the constitutional provisions involved; we do not think they hold that a municipality never has standing to sue the state of which it is a creature. In fact, correctly interpreted, these cases do not deal with "standing," in the sense in which we use the term.

\footnotetext{
bring an action under the Supremacy Clause alleging that federal law preempted state law); City of Charleston v Public Service Commission of West Virginia, 57 F3d 385, 389-90 (4th Cir 1995) (stating that there is some support for the old rule that municipalities may not sue their parent states, but that it has been applied mostly in Fourteenth Amendment cases, and that its scope is in doubt); Amato $v$ Wilentz, 952 F2d 742, 754-55 (3d Cir 1991) (noting, while deciding the question of third party standing, that the old rule is current law, but acknowledging that support for it may be waning); Benjamin v Malcolm, $803 \mathrm{~F} 2 \mathrm{~d} 46,54$ (2d Cir 1986) (noting that because the city faced direct injury from the state's alleged conduct, the city has standing to sue); United States $v$ Alabama, 791 F2d 1450, 1455 (11th Cir 1986), citing Rogers $v$ Brockette, 588 F2d 1057, 1068 (5th Cir 1979), for the principle that no per se rule denying municipal suits applies in the Eleventh Circuit; South Macomb Disposal Authority $v$ Township of Washington, 790 F2d 500, 504-05 (6th Cir 1986) (suggesting that political subdivisions may sue in some circumstances); Rogers, 588 F2d at 1068 (same); San Diego Unified Port District v Gianturco, 457 F Supp 283, 288-89 (S D Cal 1978), affd on other grounds, 651 F2d 1306, 1309 n 7 (9th Cir 1981) (allowing a municipality to bring constitutional challenges to state law based on the Supremacy Clause). See also City of South Lake Tahoe v Califormia Tahoe Regional Planning Agency, 449 US 1039, 1041-42 (1980) (White dissenting from denial of certiorari) (arguing that the Ninth Circuit's denial of political subdivision standing was "inconsistent" with the Court's holding in Board of Education v Allen, 392 US 236 (1968), that a local school board has standing to challenge a state statute requiring it to lend books to parochial schools); Star-Kist Foods, Inc $v$ County of Los Angeles, 42 Cal 3d 1, 227 Cal Rptr 391, 719 P2d 987, 990-91 (1986) (allowing municipal claims based on the Commerce Clause).

" 588 F2d 1057 (5th Cir 1979).

"US Const Art VI, cl 2 ("This Constitution, and the Laws of the United States which shall be made in Pursuance thereof... shall be the supreme Law of the Land.").

"Rogers, 588 F2d at 1059.

$\approx$ Id at 1060 .

"Id at 1068.
} 
By interpreting the decisions in Hunter and Trenton as being decided on the merits, the Rogers court was able to argue that those cases were not dispositive.

More importantly, the Rogers court suggested that considerations of federalism would not stand in the way of a municipal lawsuit: "There is every reason to think that Congress may interfere with a state's internal political organization." ${ }^{23}$

Recently, in Branson School District RE-82v Romer, ${ }^{24}$ the Tenth Circuit embraced Rogers and allowed a municipal suit that alleged that a state law conflicted with a federal law in violation of the Supremacy Clause. ${ }^{25}$ The court distinguished the Hunter line of decisions, arguing that those cases were dismissed on the merits because the Fourteenth Amendment and the Contract Clause are guarantees of individual liberty, and municipalities are not individuals under the meaning of either constitutional provision. ${ }^{26}$ In contrast, the Supremacy Clause does not protect individual rights, but rather provides for the structure of the federal government by imposing a general limitation on state power. The court concluded that the Hunter line of cases "stand[s] only for the limited proposition that a municipality may not bring a constitutional challenge against its creating state when the constitutional provision that supplies the basis for the complaint was written to protect individual rights, as opposed to collective or structural rights.",27

However, not all circuits have been so easily convinced that municipalities should enforce federal law against the states like quasiUnited States Attorneys. As a result, the Rogers line of cases is in direct conflict with the decisions of several other courts. ${ }^{28}$ For instance, in

Id at 1068-70.

Id at 1070.

21 161 F3d 619 (10th Cir 1998).

${ }^{25}$ Id at 628. In Branson, Colorado school districts brought an action against the state to enjoin enforcement of an amendment to the school trust lands article of the Colorado Constitution, arguing that the amendment violated the Colorado Enabling Act, ch 139, 18 Stat 474 (1875), a federal law. Id at 626-27.

${ }^{25}$ Id at 629.

"Id at 628.

* See Palomar Pomerado Health System v Belshe, 180 F3d 1104, 1107-08 (9th Cir 1999) (holding that political subdivision of the state lacks standing to bring a cause of action against the state in federal court); Amato, $952 \mathrm{~F} 2 \mathrm{~d}$ at 755 (finding that county did not have third-party standing to bring action against Chief Justice of the New Jersey State Supreme Court); Housing Authority of the Kaw Tribe of Indians of Oklahoma $v$ City of Ponca City, 952 F2d 1183, 1188-90 (10th Cir 1991) (holding that a political subdivision may not challenge the validity of an act by another political subdivision under the Fourteenth Amendment unless the parent state consents to such an action); Gwinn Area Community Schools v Michigan, 741 F2d 840, 844 (6th Cir 1984) (holding that school district, as a political subdivision of state, could not challenge state action); City of Safety Harbor $v$ Birchfield, 529 F2d 1251, 1254-55 (5th Cir 1976) (dismissing city's suit against state legislature for annexation of municipal territory); City of New York $v$ Richardson, 
Burbank-Glendale-Pasadena Airport Authority v City of Burbank, the Ninth Circuit recently held that municipal suits based on a violation of federal law and the Supremacy Clause are nonjusticiable. Citing earlier circuit precedent, ${ }^{31}$ the court reiterated its interpretation of the Hunter line of cases as a per se bar to municipal suits against their states, and refused to make an exception for claims arising under the Supremacy Clause. ${ }^{32}$

In a concurring opinion, Judge Kozinski argued that merely because the Supremacy Clause protects the federal government against encroachment by the states, it does not follow that municipalities have a cause of action to enforce a federal law. ${ }^{33}$ Relying on recent Supreme Court jurisprudence, ${ }^{34}$ Judge Kozinski warned federal courts to proceed with caution:

Suppose Congress passes a statute and empowers the state's Attorney General to bring a suit to set aside any state law inconsistent therewith.... Or, what if Congress bestows that power on a member of his Governor's cabinet, such as the Secretary of Transportation? ... There is a plausible argument that Congress may not interfere with the functioning of state officials and instrumentalities by endowing them with powers and duties that conflict with their responsibilities under state law.... The [impact of federalism] deserves exploration before we carve out a Supremacy Clause exception to [the rule against allowing municipal suits].

$473 \mathrm{~F} 2 \mathrm{~d} 923,929$ (2d Cir 1973) (ruling that political subdivisions of state may not challenge validity of a state statute under the Fourteenth Amendment); School District of Philadelphia $v$ Pennsylvania Milk Marketing Board, 877 F Supp 245, 250 (E D Pa 1995) (holding that school district could not bring action against state milk marketing board in which district alleged that policies of marketing board violated federal constitution).

* 136 F3d 1360 (9th Cir 1998).

s Id at 1364. In Burbank, California passed a statute that prevented the local airport authority from expanding without first submitting its plans to the Burbank City Council for approval. The airport authority, a political subdivision created by the state, brought an action against the city, claiming that state law unconstitutionally violated the Supremacy Clause by regulating air safety, an area reserved for federal regulation. Id at 1362.

"City of South Lake Tahoe v California Tahoe Regional Planning Agency, 625 F2d 231, 233 (9th Cir 1980); Indian Oasis-Baboquivari Unified School District No 40 of Pima County, Arizona $v$ Kirk, 91 F3d 1240, 1243-44 (9th Cir 1996) (denying a school district standing to challenge a state school funding program as preempted by federal law).

"Burbank, 136 F3d at 1364.

"Id at 1364-65.

* Judge Kozinski refers principally to Printz v United States, 521 US 898 (1997), which purports to be an absolute prohibition against federal commandeering of state legislative and executive officials. Id at 933. See also Part II.A.3.b.

"Burbank, 136 F3d at 1365. Despite Judge Kozinski's suggestions otherwise, Printz's prohibition on federal commandeering will rarely be determinative in deciding whether a municipality may bring a preemption claim. First, Printz involved an explicit congressional command that 
Judge Kozinski's warning is worth heeding, as considerations of federalism should inform the results courts reach on this issue. Indeed, a substantial shortcoming of the earlier cases was their failure to consider the effect that allowing municipal preemption suits would have on the integrity of the states. Conferring a cause of action upon municipalities to sue their states would seriously impede the states' autonomy in administering their own governments. Municipalities that were previously beholden to the states for all their power would suddenly have an independent federal grant of power. This would weaken the states' ability to structure their government free from worry that such a decision might be used by the federal government as a weapon against them. ${ }^{36}$ These concerns will be addressed in more detail in Parts II and III.

\section{Standing Versus Cause of Action}

As a preliminary point, it should be emphasized that several courts have mistakenly relied on the Hunter line of cases for the proposition that municipalities do not have standing to sue their parent state." Trenton and Hunter did refer to "standing." However, when those cases were decided, "standing" meant only that, on the merits, the municipality had rights under the particular constitutional provisions it invoked. ${ }^{38}$ Standing was not seen as the threshold question that

state or local officials must execute a federal program. In contrast, none of the cases examined in this Comment involve an explicit statement that a local official "must" challenge a state law; in each case, municipal officials brought the suit voluntarily.

Second, Printz is limited to laws that Congress passes under its Commerce Clause power. See Printz, 521 US at 936 (O'Connor concurring). Most of the cases in this Comment involve laws that Congress passed under some other power. For instance, of the three major cases this Comment discusses, only Burbank involved a law that Congress passed under its Commerce Clause power. In contrast, in Branson, Congress passed the Colorado Enabling Act under the Property Clause of the Constitution. Branson, 161 F3d at 635, citing US Const Art IV, $\S 3, \mathrm{cl} 2$ ("The Congress shall have Power to dispose of and make all needful Rules and Regulations respecting the Territory or other Property belonging to the United States."). And in Rogers, Congress passed the school lunch plan under its power to spend for the general welfare. Rogers, 588 F2d at 1071, citing US Const Art I, \$ 8, cl 1. See also Gwinn Area Community Schools, 741 F2d at 840 (spending power); Richardson, 473 F2d at 923 (spending power). But see Pennsylvania Milk Marketing Board, 877 F Supp at 245 (commerce power); Gianturco, 457 F Supp at 283 (commerce power); Star-Kist Foods, Inc, 719 P2d at 987 (commerce power).

On its own, it is doubtful how often Printz will serve to prevent municipalities from challenging the laws of their parent states. However, the policies on which Printz is grounded suggest that federal courts ought not allow municipal preemption challenges.

- For examples of how the federal government can turn a state against itself see Part II.A.3 and the text accompanying note 54.

"See, for example, Burbank, 136 F3d at 1363-64; Gwinn Area Community Schools v Michigan, 741 F2d 840, 844 (6th Cir 1984); City of South Lake Tahoe v California Tahoe Regional Planning Agency, 625 F2d 231,233-34 (9th Cir 1980); School District of Philadelphia v Pennsylvania Milk Marketing Board, 877 F Supp 245, 250-51 (E D Pa 1995).

${ }^{33}$ Rogers, 588 F2d at 1070 (highlighting the difference between standing and cause of ac- 
it is today. Thus, both Hunter and Trenton stand for the proposition that municipalities are unable to state a cause of action under the Fourteenth Amendment and the Contract Clause because those provisions protect the interests of individuals only, not municipalities. Accordingly, this Comment will examine whether municipalities have a cause of action to sue their parent state, not whether they have standing to sue.

In fact, in the majority of the cases discussed in this Comment, the municipalities satisfy modern standing doctrine, which requires a plaintiff to satisfy three requirements. First, she must show she has suffered (or is likely to suffer) an "injury-in-fact." Second, there must be a causal connection between the injury and the conduct complained of. Finally, it must be likely that a favorable decision by the court will redress the plaintiff's injury. ${ }^{39}$ In terms of injury-in-fact and causation, the airport authority in Burbank would suffer a competitive disadvantage if it were not permitted to expand its operations, just as the school districts in Rogers and Branson would suffer financial hardship if the respective state laws were enforced. In these cases, the hardship could be redressed by a judicial determination that the state law is preempted by a federal law.

However, while municipalities may not lack "standing" in the modern sense of the term, the question whether municipalities have a claim on the merits often remains a threshold issue." While the standing/cause of action distinction is not always important to the fi-

tion). See also William A. Fletcher, The Structure of Standing, 98 Yale L J 221, 224-25 (1988) (identifying modern standing doctrine as a product of the second half of the twentieth century: "It is at least clear that current standing law is a relatively recent creation. In the late nineteenth and early twentieth centuries, ... no general doctrine of standing existed. Nor, indeed, was the term 'standing' used as the doctrinal heading under which a person's right to sue was determined."); Cass R. Sunstein, What's Standing After Lujan? Of Citizen Suits, "Injuries," and Article III, 91 Mich L Rev 163, 170-80 (1992) (arguing that in the years leading up to the New Deal, there was no separate standing doctrine).

s See Federal Election Commission v Akins, 524 US 11, 19 (1998) (holding that voters seeking information under the Federal Election Campaign Act of 1971, 2 USC $\S 431$ (4) (1994), have standing to challenge agency's decision not to bring an enforcement action); Bennett $v$ Spear, 520 US 154, 162 (1997); Lujan v Defenders of Wildlife, 504 US 555, 560-561, 568-71 (1992) (finding wildlife conservationists lacked standing to challenge an agency rule because they did not demonstrate that they suffered an injury in fact, nor that their alleged injury was redressable). In addition, the Supreme Court has held that making generalized grievances against the government "does not state an Article III case or controversy." See Lujan, 504 US at 573-74. However, in light of the Court's recent holding in Akins, it is no longer clear what remains of the ban on generalized grievances. See, for example, Cass R. Sunstein, Informational Regulation and Informational Standing: Akins and Beyond, 147 U Pa L Rev 613, 643-48 (1999) (arguing that while the Court's decision in Akins limited its previous holding in Lujan, it is unlikely that Akins completely eliminates the generalized grievance proscription).

" See David P. Currie, Misunderstanding Standing, 1981 S Ct Rev 41, 43 ("Whether the answer is labeled 'standing' or 'cause of action,' the question is whether the statute or Constitution implicitly authorizes the plaintiff to sue."). 
nal result, classifying the two correctly helps to explain why the courts that refuse to hear municipal preemption suits do not apply modern standing doctrine.

The real issue then is not standing. Rather it is whether Congress has constitutional authority to grant a municipality a cause of action to enforce federal law, and if so, whether Congress has granted such authority in the particular case. Considerations of federalism and of the Supreme Court's canons of construction suggest that the answer to both questions is "no."

\section{CONGRESS MAY NOT HAVE THE AUTHORITY TO GRANT MUNICIPALITIES AN IMPLIED CAUSE OF ACTION TO SUE THE STATE}

It is questionable whether Congress has the authority to grant municipalities either an express or implied cause of action to sue their parent states. This Comment refers to implied causes of action because none of the relevant cases involve an explicit congressional conferral of a cause of action to municipalities. Subpart A considers whether Congress has authority to grant these causes of action. Subpart B suggests that these disputes can be resolved within the state political process with fewer constitutional problems. Finally, Subpart C identifies what courts find troubling about refusing to adjudicate municipal preemption suits.

\section{A. Congress's Constitutional Authority to Confer a Cause of Action upon Municipalities to Sue Their Parent States}

The failure of both the Burbank and Rogers lines of cases to consider whether Congress has the authority to interfere with a state's internal political organization is a major flaw in their analyses. Such consideration is necessary because the answer to the narrower question of justiciability has implications on the larger debate about the balance of power between the states and the federal government. By holding that a municipality has a cause of action against its state, and suggesting that Congress is able to limit states' control of their municipalities, the Rogers line of cases has reduced the states' control over their internal governments. Such congressional interference may not be constitutionally permissible.

\section{Constitutional text.}

The Framers of the Constitution were deliberate in their efforts to distribute power among various government entities. They structured the Constitution to allocate power and provide checks and balances between federal and state government. Nevertheless, the text of the Constitution provides no basis for finding that municipalities have 
a status independent from that of the state. ${ }^{41}$ In fact, the Constitution makes no provision for local government at all. As the Court stated recently in the related context of Eleventh Amendment immunity in Alden v Maine," "the silence is most instructive." ${ }^{43}$ The silence of the text suggests similarly that states' control over municipalities "was a principle so well established that no one conceived it would be altered by the new Constitution."

There are several examples in the text where the Constitution reserves powers for the states but makes no reservation of independent powers for municipalities. For instance, the Tenth Amendment reserves the residual powers of government to the "States respectively, or to the people." ${ }^{45}$ Among the most important of these residual powers is state lawmaking authority: states can legislate without first having to secure federal permission. In contrast, local governments lack inherent lawmaking authority: they can only act if the state has granted them the authority. ${ }^{46}$

Second, Article IV, Section 3 guarantees the states fixed boundaries which cannot be changed without their consent. ${ }^{47}$ In contrast, municipalities are subject to a state's decision to change their boundaries or even to revoke their corporate charter, thus eliminating them entirely.

Finally, the Constitution guarantees that "no new State shall be formed or erected within the Jurisdiction of any other State." $"$ This provision not only protects the integrity of State borders, but also guarantees that every citizen will have an allegiance to only one state.

Consider US Const Amend X (referring only to the federal government, states, and the people as entities among which governmental power is distributed).

119 S Ct 2240 (1999).

"Id at 2260 (arguing that the ratification debates surrounding the Eleventh Amendment did not include any mention of the Founders' intent to preserve states' immunity from suit in their own courts because this principle was established beyond question).

"Id.

* US Const Amend X.

4s For instance, states usually prevent or strictly limit localities' ability to legislate to raise money or regulate core areas of the law such as contract, tort, and criminal law. See Richard Briffault, "What About the 'Ism'?" Normative and Formal Concerns in Contemporary Federalism, 47 Vand L Rev 1303, 1339-43 (1994).

" US Const Art IV, $\S 3, \mathrm{cl} 1$ ("[N]o new State shall be formed or erected within the Jurisdiction of any other State; nor any State be formed by the Junction of two or more States, or Parts of States, without the Consent of the Legislatures of the States concerned as well as of the Congress.").

Id.

"The Framers were aware that in order to make states an effective balance to federal power, the states would need to be able to instill loyalty in their citizens. See, for example, Federalist 45 (Madison), in Clinton Rossiter, ed, The Federalist Papers 290-91 (Mentor 1961) (discussing the states' comparative advantage in "the predilection and probable support of the people" as an important check on federal power). In contrast, the Framers did not establish such protection for municipalities for two reasons. First, based on size, municipalities could not balance fed- 


\section{Constitutional structure.}

Beyond the text, there are structural reasons to limit federal control over municipalities. Allowing these suits impedes states' sovereignty by giving their municipalities a federal right with which to exert their wills outside of the states' political process. Doing so may be inconsistent with the Supreme Court's repeated assertions about the importance of sovereign states in our federal system. ${ }^{\text {s0 }}$ States serve as the repositories of the reserved powers under the Constitution, and thereby protect citizens from oppression by providing a check on the powers of the federal government.

Allowing an expansion of municipal power at the expense of the states would be less problematic if municipalities could provide a check on federal power as well as states can. However, this is not the case. Permanent existence, territorial integrity, and inherent lawmaking and fund-raising authority tend to make states more effective political actors than localities, which lack these qualities. ${ }^{51}$

The permanence of states also has given them a special role in the consciousness of citizens. This in turn reinforces their political position vis-à-vis the federal government. ${ }^{52}$ The ability of states to enact laws and to create lower levels of state and municipal government builds citizen loyalty to them. ${ }^{53}$ This is a primary way that allowing a municipal cause of action can weaken the states: states sued by their own municipalities will suffer a blow to their dignity. ${ }^{4}$ While states do not

eral power effectively, even with the most loyal citizenry. Second, the various forms of municipal government are generally less important to their citizens and garner less citizen loyalty than do the states. They are not as static a force in citizens' lives both because their boundaries are subject to change, and because citizens are often under the jurisdictions of several municipalities, such as city, county and school district, at the same time. See Briffault, 47 Vand L Rev at 1335-39, $1344-45$ (cited in note 46 ).

See cases cited in note 118 .

st See discussion in note 49.

Id at 1345-46.

The Framers believed that a state government would secure the loyalty of its citizens by providing them with the opportunity to become involved in local government:

By the superintending care of [state offices and emoluments], all the more domestic and personal interests of the people will be regulated and provided for. With the affairs of these, the people will be more familiarly and minutely conversant. And with the members of these will a greater proportion of the people have ties of personal acquaintance and friendship.

Federalist 46 (Madison), in Rossiter, ed, Federalist Papers at 294-95 (cited in note 49). To ensure this political participation at the local level, states need to have the authority to organize the offices provided for the people. See also Federalist 16 (Hamilton), in Rossiter, ed, Federalist Papers at 116 ("[State government] must be able to address itself immediately to the hopes and fears of individuals."); Robert F. Nagel, Federalism as a Fundamental Value: National League of Cities in Perspective, 1981 S Ct Rev 81, 103 (arguing that the Framers understood that "to be able to protect themselves in the political process states would need (and were assured under the proposed Constitution) the capacity to elicit loyalty by providing for the needs of their residents").

* The Supreme Court recently endorsed the importance of preserving state dignity in the 
suffer embarrassment in the same sense that people do, they do suffer a symbolic blow because in the eyes of their citizens the states' authority has been weakened. ${ }^{\text {ss }}$

Granting a cause of action to municipalities weakens the state from within. This in turn weakens the extent to which the states can act as a check on federal power.

\section{Supreme Court precedent.}

Recently, the Supreme Court has reaffirmed the importance of states' autonomy, creating limitations on both federal interference in states' internal political organization and federal commandeering of state resources. By analogy, these decisions suggest that Congress may lack authority to grant municipalities an implied cause of action to sue their parent states.

a) Interference with the states' internal political organization. While the Supreme Court has identified constitutional limits on states' control of their municipalities, it is questionable whether the limits should enable Congress to provide municipalities with a cause of action against their parent states. A fundamental aspect of state sovereignty is the states' ability to structure state and local government as they see fit. This line was drawn as far back as 1911 in Coyle $v$ Smith, where the Supreme Court forbade the federal government from ordering the State of Oklahoma where to locate its capital.

The Court further elucidated this idea in Gregory $v$ Ashcroft. ${ }^{88}$ In that case, Missouri state judges challenged a mandatory retirement provision in the state constitution, arguing that it violated the federal Age Discrimination in Employment Act of $1967 .{ }^{59}$ In upholding the state provision, Justice O'Connor was persuaded by how important

related context of Eleventh Amendment jurisprudence: "The Eleventh Amendment does not exist solely in order to 'preven[t] federal court judgments that must be paid out of a State's treasury, it also serves to avoid 'the indignity of subjecting a State to the coercive process of judicial tribunals at the instance of private parties." Seminole Tribe of Florida $v$ Florida, 517 US 44, 58 (1996) (citations omitted).

"Id.

* See, for example, Romer v Evans, 517 US 620, 626, 629-31 (1996) (holding that Equal Protection Clause precludes a state from prohibiting local governments from instituting laws designed to protect homosexual persons from discrimination); Kramer v Union Free School Dist No 15, 395 US 621, 628-29 (1969) (holding that Equal Protection Clause precludes states from imposing certain limitations on eligibility to vote in school board elections); Gomillion v Lightfoot, 364 US 339, 343-45 (1960) (holding that state control of municipalities cannot be used to circumvent Fifteenth Amendment right to vote). While these cases discuss limitations on state power, as discussed in Part II.C.1, they are not relevant to the question whether municipalities should have a cause of action to enforce federal preemption of state law.

221 US 559,565 (1911).

501 US 452, 460 (1991).

" 29 USC $\$ \$ 621-34$ (1994). 
filling political positions within its government was to the autonomy of the state:

The present case concerns a state constitutional provision through which the people of Missouri establish a qualification for those who sit as their judges. This provision goes beyond an area traditionally regulated by the States; it is a decision of the most fundamental sort for a sovereign entity. Through the structure of its government, and the character of those who exercise government authority, a State defines itself as a sovereign. ${ }^{60}$

The case most closely analogous to the issue of municipal preemption suits is Alden v Maine. In Alden, state officers sued the State of Maine in its own courts for violation of the overtime provisions of the Fair Labor Standards Act (FLSA). ${ }^{62}$ The Supreme Court held that under the Eleventh Amendment, the federal government could not subject a state to suit in its own courts without the state's consent. Justice Kennedy warned that states should be able to create subordinate branches without fear that the federal government would be able to use them as a weapon against the state:

A power to press a State's own courts into federal service to coerce the other branches of the State [ ] is the power to turn the State against itself and ultimately to commandeer the entire political machinery of the State against its will and at the behest of individuals. Such plenary federal control of state governmental processes denigrates the separate sovereignty of the states. ${ }^{63}$

The offense to state sovereignty that troubled the Court in Alden, Gregory, and Coyle also looms over the question of municipal preemption suits. Like their courts, states create municipalities to serve a particular role within the state government. Allowing the federal government to use these state bodies to litigate against the states is as offensive to state sovereignty as allowing the federal government to use the states' courts against them.

b) Commandeering/unfunded mandates. In some ways, granting municipalities a cause of action to enforce federal law is similar to the

\footnotetext{
" Gregory, 501 US at 460 (emphasis added), citing Taylor $v$ Beckham, 178 US 548, 570-71 (1900) ("It is obviously essential to the independence of the States, and to their peace and tranquility, that their power to prescribe the qualifications of their own officers ... should be exclusive, and free from external interference, except so far as plainly provided by the Constitution of the United States."). See also Boyd v Nebraska, 143 US 135, 161 (1892) ("Each State has the power to prescribe the qualifications of its officers and the manner in which they shall be chosen.").

"119 S Ct 2240 (1999).

29 USC $\$ \$ 201$ et seq (1994).

alden, 119 S Ct at 2264 (citation omitted).
} 
type of federal commandeering of which the Supreme Court disapproves. Like commandeering, allowing municipal preemption suits forces states to absorb the financial burden of enforcing a federal law.

Two recent cases illustrate the Court's hostility to federal commandeering. First, in New York $v$ United States, ${ }^{64}$ the Court held that a federal statute, which gave states a choice of either regulating the disposal of local radioactive waste or "taking title" to it, exceeded Congress's constitutional authority. ${ }^{65}$ The Court was troubled that states would have to expend their resources to enforce a federal policy. ${ }^{\infty}$ With this in mind, the Court determined that the first provision of the act, which required states to "take title" to radioactive waste, amounted to a "congressionally compelled subsidy from state governments to radioactive waste producers" and, therefore, exceeded Congress's constitutional authority.

Likewise, in United States $v$ Printz, ${ }^{\circ}$ the Supreme Court held that the Brady Handgun Violence Prevention Act of 1993 ("Brady Act")," exceeded Congress's authority by commandeering state officials. ${ }^{70}$ The Brady Act required state or local law enforcement officers to analyze information on prospective gun buyers to "make a reasonable effort to ascertain" whether the prospective buyer could legally own a handgun." As in New York, the Court was troubled that this federal plan amounted to an unfunded federal mandate on the states: "By forcing state governments to absorb the financial burden of implementing a federal regulatory program, Members of Congress can take credit for 'solving' problems without having to ask their constituents to pay for the solutions with higher federal taxes."

The dangers caused by federal commandeering of which the Supreme Court warned in New York and Printz are equally applicable to municipal preemption suits. ${ }^{73}$ Allowing municipal preemption suits

“ 505 US 144 (1992).

Id at 149-50.

"Id at 177 ("The [Act] offers a state government no option other than that of implementing legislation enacted by Congress.").

"Id at 175-76. The Court also held that Congress lacked authority to force states to accept the second alternative, which was to directly regulate the waste. The Court therefore found that the act did not present the states with a choice at all, but rather amounted to federal coercion, stating that "a choice between two unconstitutionally coercive regulatory techniques is no choice at all." Id at 176.

“ 521 US 898 (1997).

$\Rightarrow 18$ USC $\$ 922$ (1994).

Printz,521 US at 935 .

"Id at 903-04.

${ }^{n}$ Id at 930 . The Court also argued that federal commandeering of state legislative and executive officials was unconstitutional because it (a) impedes state sovereignty, and (b) leaves federal officials less politically accountable. Id at 928-30.

"Importantly, the Court in Printz rejected the dissent's distinction between commandeering of state and local officials. Id at $931 \& \mathrm{n} 15$. See also id at $955 \& \mathrm{n} 16$ (Stevens dissenting) (argu- 
amounts to an unfunded mandate in that it forces states to absorb the financial burden of enforcing federal preemption claims. If municipalities are denied a cause of action to bring federal preemption claims against state laws, then the litigation expense of enforcing federal laws will fall entirely on the federal government. ${ }^{74}$ However, allowing municipalities to bring such suits, even voluntarily, shifts the financial burden of enforcing federal law away from the federal government. Additionally, crowding state and municipal agendas with federal programs, and allowing municipalities to enforce them, can limit the capacity of states and municipalities to pursue their own locally initiated programs. ${ }^{75}$

\section{B. The Political Process: Alternative Dispute Resolution}

Municipalities do not need court protection for their interests, because they are already protected in the state political system. $\mathrm{Mu}$ nicipalities have been set up by the state to aid in the provision of services to its citizens and to help the state execute its laws. If there is a conflict between the state and the municipalities, it amounts to a political conflict. The state lawmaking process is the exclusive forum for working out controversies between a state and its municipalities. Citizens are fully represented, and their grievances are resolvable by, the state legislature. Therefore, there is no judicially cognizable conflict between the generalized interest of the state and the parochial interests asserted by local governments. ${ }^{76}$

Admittedly, state political systems often do not provide municipalities with the same structural safeguards that the federal system provides to the states. While states send Senators to represent their interests, and while the states were originally granted a role in presidential election by means of the electoral college, municipalities usually are not represented as municipalities in the state legislatures. However, the absence of these structural safeguards in the state political system is less important in practice. While the city of Chicago may not

\footnotetext{
ing that the Court's Eleventh Amendment jurisprudence distinguished between municipal and state officials).

"Even without municipal enforcers, federal government attorneys always have standing and cause to challenge state preemption of federal law. See Part II.C.2.

"See Candice Hoke, Constitutional Impediments to National Health Reform: Tenth Amendment and Spending Clause Hurdles, 21 Hastings Const L Q 489, 549 (1994) (suggesting that federal health care legislation would violate the Tenth Amendment to the extent that it would interfere with the states' control over their political agendas and limit state efforts to engage in experimentation with new programs).

"But see Michael E. Libonati, Intergovernmental Relations in State Constitutional Law: A Historical Overview, 496 Annals of Am Acad of Pol \& Soc Sci 107, 114-15 (March 1998) (endorsing the holdings of several state supreme courts that municipalities have interests distinct from the state that cannot be adequately addressed in the state legislature).
} 
have its own state senators, it would be far-fetched to say that it does not have a voice in the state political process."

There is evidence that municipalities, currently, are well represented in the political process. The fact that many states have altered their constitutions to provide for "local home rule" illustrates that the state political process is responsive to local preferences. ${ }^{78}$ Home rule provides local governments with control over their own affairs such as taxation and the provision of services. Additionally, several states, responding to local demand, now consent to suits brought by their municipalities. ${ }^{79}$ This willingness reflects the municipalities' strength in the political arena.

The case of Branson exemplifies how intervention by federal courts can interfere with a well functioning political process and thereby thwart a state's ability to manage its internal affairs. In Branson, Colorado voters, in a statewide election, approved a ballot initiative to amend the Colorado Constitution. ${ }^{30}$ However, the coalition that had campaigned against the amendment and had failed in the political process then turned to the courts. Unable to show a sufficiently particularized injury to prove their individual standing, the coalition's members brought suit in the name of three school districts. ${ }^{\text {st }}$ Their objective was simple: they would ask a federal court to overturn the election results and dictate to the state how it could fund its school system. The court agreed to hear the suit on the grounds that the $\mathrm{Su}$ premacy Clause demands that federal laws always be enforced. However, by allowing the suit, the court gave a political minority, which had lost in a statewide election, a second bite at the apple. In the process, the federal court implicitly acknowledged that it, and not

"See Briffault, 47 Vand L Rev at 1318 (cited in note 46) ("Indeed, despite their formal status as political subdivisions of the state, most general purpose local governments-counties and municipalities-are primarily accountable to their local electorates. In practice, they function as representatives of local constituencies and not as field offices for state bureaucracies").

"Id at 1319 ("The political rallying cry of 'home rule' or 'local control' has frequently been potent enough to block challenges to local autonomy based on claims of equality, individual rights, or the external effects of local action.").

See Richard Briffault, Our Localism: Part I-The Structure of Local Government Law, 90 Colum L Rev 1, 10-11 (1990) (discussing two general models of home rule provisions); Melvin B. Hill, State Laws Governing Local Structure and Administration 43 (Georgia 1978) (stating that by 1978 forty-one states had granted at least some home rule authority to their cities).

Among other things, the amendment changed the previous requirement that the Colorado land board manage its holdings "in such manner as will secure the maximum possible amount" of revenue for the Colorado public school fund. Instead, the amendment required the land board to manage its holdings "in order to produce a reasonable and consistent income over time." Branson, 161 F3d at $626-27$. The school districts argued this amendment was preempted by the federal Colorado Enabling Act, ch 139, 18 Stat 474 (1875).

"Branson, $161 \mathrm{F3d}$ at 627-28.

Id at 626-27.

Id at 630 . 
the state, would decide the proper way for the state to organize and fund its internal political structure.

Perhaps the court might have decided differently if it had been privy to the Supreme Court's words in Alden v Maine:

If the principle of representative government is to be preserved to the States, the balance between competing interests must be reached after deliberation by the political process established by the citizens of the State, not by judicial decree mandated by the Federal Government. ${ }^{84}$

Instead, the Branson court's decision to allow the municipal suit is an example of judicial activism that prudential courts should seek to avoid.

C. Identifying What Courts Really Find Troubling about Refusing to Adjudicate Municipal Preemption Suits

1. Fear that state violations of individual rights will go unenforced.

One misplaced concern is that if municipalities cannot sue their states, state violations of individual rights will be unenforceable. However, in most cases, when individual rights are violated, individuals will have both standing and a cause of action to sue. ${ }^{s 6}$ The only time when these rights conceivably might be underenforced is when individual plaintiffs are denied standing because their grievance is not sufficiently particularized. However, to the extent courts find this result offensive, they should reform the standing rules that bar these individual suits. In fact, the Supreme Court's recent decision in Federal Election Commission v Akins, ${ }^{87}$ which eased the ban on generalized grievance claims, ${ }^{\Re}$ might be read as the first step in that direction. This approach is preferable to creating new municipal rights, which weakens state sovereignty.

$119 \mathrm{~S} \mathrm{Ct}$ at 2265.

* See Antonin Scalia, The Doctrine of Standing as an Essential Element of the Separation of Powers, 17 Suffolk L Rev 881, 894-97 (1983) (arguing that standing doctrine, by restricting courts to redressing the injuries of individuals, prevents courts from interfering in the legislative process).

"Generally, these cases have all involved challenges under the Fourteenth Amendment, for which Section 1983 provides a cause of action. See 42 USC \& 1983 (1994) (allowing recovery against any person who, "under color" of any state law, subjects another person to the deprivation of any constitutional right).

" 524 US 11, 24 (1998) ("[W]here harm is concrete, though widely shared, the Court has found 'injury in fact."').

see Lujan v Defenders of Wildlife, 504 US 555,573-74 (1992) (stating that making a claim of injury to the "public at large" against the government "does not state an Article III case or controversy"). 
Additionally, it does not follow from the fact that the Court has ruled on the merits of cases like Romer $v$ Evans, ${ }^{\text {s" }}$ Washington $v$ Seattle School District No $1,{ }^{\text {, }}$ and Gomillion v Lightfoot, that municipal suits are justiciable. ${ }^{2}$ It is true that the Court heard cases like Romer $v E v$ ans on the merits and limited states' control over their municipalities. However, these cases all involved violations of individuals' Fourteenth Amendment rights. ${ }^{93}$ The issue of the justiciability of municipal suits was not raised. For instance, in Romer $v$ Evans the question whether the municipality had a cause of action was passed sub silentio because there were individual plaintiffs who presented a justiciable case. ${ }^{\text {s. }}$ The Court did not need to raise the issue whether the municipality was a valid plaintiff because nothing turned on it."

For situations such as this, the Supreme Court has held that one cannot infer from the fact that the Court decided a case on the merits that the issue of jurisdiction has been answered: "[A]s to our own judicial power on jurisdiction, this Court has followed the lead of Mr. Chief Justice Marshall who held that this Court is not bound by a prior exercise of jurisdiction in a case where it was not questioned and it was passed sub silentio." The modern Court has not addressed the jurisdiction issue of municipal preemption suits, and the Rogers line of

* 517 US 620 (1996) (holding that the Equal Protection Clause precludes a state from prohibiting local governments from instituting laws designed to protect homosexual persons from discrimination).

* 458 US 457,474-82 (1982) (holding that a state may not remove authority over integrative busing from local school boards).

" 364 US 339 (1960) (holding that a state may not control municipalities to circumvent the right to vote provisions of the Fifteenth Amendment).

"The Rogers line of cases arrived at a contrary interpretation of these cases. See Rogers, 588 F2d at 1068 (arguing that Gomillion limits the rationale of Hunter to the Fourteenth Amendment and the Contract Clause); Branson School District RE-82 v Romer, 958 F Supp 1501, 150708 (D Colo 1997) (agreeing with courts that have held that standing is appropriate when there are claims based on the Supremacy Clause), affd, 161 F3d 639 (10th Cir 1998); San Diego Unified Port District v Gianturco, 457 F Supp 283, 290 (S D Cal 1978) (noting that no authority has been cited for the proposition that an action brought by a political subdivision against a state based on the Supremacy Clause is barred).

"See, for example, Romer v Evans, 517 US at 632; Seattle School District, 458 US at 476; Kramer v Union Free School District No 15, 395 US 621, 631-33 (1969) (holding that Equal Protection Clause precludes states from imposing certain limitations on eligibility to vote in school board elections).

"Romer v Evans, 517 US at 625.

" Additionally, there is a well established canon that counsels the Court to avoid raising difficult constitutional questions unnecessarily. See Part III.A.

* United States v Los Angeles Tucker Truck Lines, Inc, 344 US 33, 38 (1952). See also Indian Oasis-Baboquivari Unified School District No 40 of Pima County, Arizona v Kirk, 91 F3d 1240, 1243-44 (9th $\mathrm{Cir} 1996$ ) (arguing that the fact the Supreme Court exercised jurisdiction in Washington $v$ Seattle School District, 458 US 457 (1982), is not precedent for the exercise of jurisdiction, and therefore refusing to entertain school districts' suit for injunctive relief against the State of Arizona). 
cases misreads Supreme Court precedent to the extent it assumes that the Court has settled the question.

2. Fear that state violations of federal law will go unenforced.

A second exaggerated concern is that without municipal challenges, a state action that violates a federal law might remain unchallenged. However, even without municipal enforcers, federal government attorneys always will have standing and cause to challenge state preemption of federal law.

Concededly, it is plausible to imagine a scenario in which municipalities are the only parties affected by a state action and federal executive officials fail to bring a preemption claim because they lack sufficient funding, time, or incentive. In these rare cases, courts must decide which is more important: remedying an arguable encroachment of federal law or respecting states' freedom to organize their political structure.

Certainly this is not an easy decision, but there are two reasons for courts to favor restraint. First, when the federal government opts not to challenge an "encroachment," it is often because the language of the federal law is ambiguous and, therefore, it is unclear whether it actually conflicts with state law. ${ }^{97}$ In these cases, where federal officials have failed to express an interest in enforcing the "violation" and the two laws could be read to be in harmony, the costs of allowing these suits may outweigh the benefits. The main risk is that the municipalities will use the ambiguous federal law as another weapon in their struggle with the state government. Courts are best advised to let the local political process resolve these disputes. ${ }^{98}$

Second, recent Supreme Court decisions suggest that the current Court may favor respecting state sovereignty over ensuring that every possible federal claim is enforced. By way of example, consider Alden $v$ Maine. There, the Court already had ruled that a state's sovereign immunity meant that the state could not be sued in federal court. ${ }^{\text {s. As }}$ a result, the Court's decision in Alden closed the only other avenue for employees to try to force a state to comply with federal law-namely, by bringing a lawsuit in state court. The Court's decision in Alden thus

"Rogers itself is the best example of this phenomenon. In Rogers, the school district sued to enforce a federal law that contained unclear terms. Rogers, 588 F2d at 1059 ("Congress left it unclear whether the choice to participate is to be made by the individual school, the local school board, or the state."). In the end, the court avoided tough decisions about its invasion of state sovereignty by interpreting the federal statute in a way consistent with the state law at issue. Id at $1070-71$.

* The Supreme Court's clear-statement rules of statutory interpretation, which will be considered in Part III, address just such a concern.

"See Seminole Tribe of Florida v Florida, 517 US 44, 72-73 (1996) (holding that Congress lacks power under Article I to abrogate the states' sovereign immunity in federal court). 
leaves enforcement to individual federal agencies, even though government lawyers argued that the Department of Labor does not have the resources to sue every time there is a complaint. ${ }^{100}$

Additionally, the Court's refusal in Printz to balance the federal interest with the burden it imposes on state sovereignty deserves to be underscored. Instead of considering the federal interest at stake, the Printz Court emphatically held: "We adhere to that principle today, and conclude categorically, as we concluded categorically in $\mathrm{New}$ York: 'The Federal Government may not compel the States to enact or administer a federal regulatory program." "101 Both Printz and Alden suggest that the balance between allowing federal courts to vindicate federal rights and respecting states' rights to order the processes of their own governance is tilted, if only slightly, in favor of the states.

\section{PRUDENTIAL CONSTRAINTS FOR ARTICLE III COURTS}

Even if the Constitution does not prevent Congress from providing municipalities with an implied cause of action to challenge state law, federal courts should not interpret federal statutes to have done so. There are numerous canons of construction designed to limit courts' involvement in these disputes. Among them are the rule to avoid constructions of statutes that would raise serious constitutional problems; the presumption against implying causes of action into federal statutes; and the rule requiring a clear statement of congressional intent before a court will abrogate states' sovereignty. Additionally, there are practical reasons for courts to defer to the state and local political process.

\section{A. Canon to Avoid Constitutional Questions}

The first relevant canon of construction is the rule that courts should interpret ambiguous statutes in such a way as to avoid constitutional difficulties. ${ }^{102}$ This canon suggests that courts should interpret federal statutes so as not to give municipalities an implied cause of action, thereby eliminating the hard questions about Congress's consti-

\footnotetext{
${ }^{\mathrm{t}}$ Alden, $119 \mathrm{~S} \mathrm{Ct}$ at 2269.

Printz, 521 US at 933, citing New York, 505 US at 188.

See, for example, Department of Commerce $v$ United States House of Representatives, $119 \mathrm{~S}$ $\mathrm{Ct} 765,781$ (1999) (Scalia concurring) (stating that in the absence of clear congressional intent, "it is our practice to construe the text in such fashion as to avoid serious constitutional doubt"); Burns v United States, 501 US 129, 138 (1991) (interpreting, in the absence of a clear statement from Congress to the alternative, Rule 32 of the Sentencing Guidelines in such a way as to avoid confronting serious questions under the Due Process Clause); Edward J. DeBartolo Corp $v$ Florida Gulf Coast Building and Construction Trades Council, 485 US 568, 575 (1988). See also Rust $v$ Sullivan, 500 US 173, 190-91 (1991) (noting that the canon of avoidance is "followed out of respect for Congress, which [the Court] assume[s] legislates in light of constitutional limitations").
} 
tutional authority to confer such a right on municipalities at the expense of state sovereignty.

Courts seek to interpret ambiguous statutes in a way that avoids constitutional difficulties for several reasons. First, based on judicial modesty, courts prefer not to consider constitutional issues when it is unnecessary to do so. Second, this canon is a clear rule that allows legislators to anticipate, ex ante, the interpretive regime that courts will apply to their statutes. This in turn allows legislators to draft statutes more efficiently, since they need not waste time worrying about how various courts might interpret their language. ${ }^{1 / 3}$ Finally, the canon is democracy-enhancing, because it forces Congress to address hard political questions instead of passing them to the courts. Forcing legislators to be clear about their decisions is desirable, because the legislative process involves public scrutiny and participation, and legislators are the officials who are most accountable to the people. ${ }^{104}$

The Rehnquist Court has used this canon on a consistent basis. ${ }^{105}$ For instance, in Edward J. DeBartolo Corp v Florida Gulf Coast Building and Construction Trades Council, ${ }^{106}$ the Court adopted an interpretation of Section 8(b)(4) of the National Labor Relations Act ${ }^{100}$ so as to avoid raising any serious First Amendment concerns. Explaining its choice of interpretation, the Court held: "[W] here an otherwise acceptable construction of a statute would raise serious constitutional problems, the Court will construe the statute to avoid such problems unless such construction is plainly contrary to the intent of Congress." "108

The prudence the Court has shown in cases like DeBartolo should serve as a guide for courts deciding the question of municipal causes of action. Part II demonstrated that the decision whether Congress has authority to confer an implied cause of action upon municipalities has weighty constitutional repercussions. Courts should exercise prudence by interpreting the particular federal statute in a way that does not raise these constitutional questions-namely, by ruling that the statute does not confer an implied cause of action upon municipalities.

\footnotetext{
${ }^{100}$ William N. Eskridge, Jr., Dynamic Statutory Interpretation 276-77 (Harvard 1994) (offering an economic justification for the canons of construction).

${ }^{13}$ Id at 286-87 ("The rule makes it harder for Congress to enact constitutionally questionable statutes and forces legislators to reflect and deliberate before plunging into constitutionally sensitive issues... Ultimately, such rules may even be democracy-enhancing by focusing the political process on the values enshrined in the Constitution.").

tos See note 102.

1x 485 US 568 (1988).

tm 29 USC \& 154(b)(4) (1994).

DeBartolo Corp, 485 US at 575.
} 


\section{B. Canon against Implied Causes of Action}

The next relevant canon of construction is the presumption against interpreting federal statutes to contain an implied cause of action. ${ }^{109}$ This canon suggests that courts should not read into federal statutes an implied cause of action for municipalities to enforce federal law.

Over the past twenty years, the Court increasingly has been unwilling to find implied causes of action in federal statutes. In Cort $v$ $A s h,{ }^{10}$ the cornerstone of the modern doctrine, the Court announced a four-part approach which focused on legislative intent and determinations of congressional purpose and traditional areas of state regulation." However, the Court's recent decisions have focused mainly on congressional intent, stating that a court should not find an implied cause of action unless there is clear evidence that Congress intended for the cause of action to exist. ${ }^{12}$ Justice Scalia has gone so far as to argue that courts should never infer an implied cause of action..$^{1.3}$ Although the rest of the Court has not adopted Justice Scalia's view, many of the Court's recent opinions have refused to find a cause of action without a plain statement from Congress. ${ }^{114}$

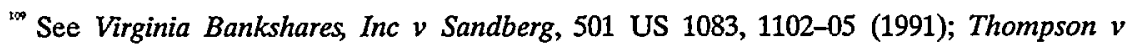
Thompson, 484 US 174, 179 (1988). See also William N. Eskridge, Jr. and Philip P. Frickey, The Supreme Court, 1993 Term-Foreword: Law as Equilibrium, 108 Harv L Rev 26, 102 (1994) (asserting that there is a judicial presumption against implying federal causes of action).

"1"422 US 66 (1975).

"' The actual four-part test is as follows:

In determining whether a private remedy is implicit in a statute not expressly providing one, several factors are relevant. First, is the plaintiff one of the class for whose especial benefit the statute was enacted, that is does the statute create a federal right in favor of the plaintiff? Second, is there any indication of legislative intent, explicit or implicit, either to create such a remedy or to deny one? Third, is it consistent with the underlying purposes of the legislative scheme to imply such a remedy for the plaintiff? And finally, is the cause of action one traditionally relegated to state law, in an area basically the concern of the States, so that it would be inappropriate to infer a cause of action based solely on federal law?

Id at 78 (citations omitted).

${ }^{112}$ See Virginia Bankshares, 501 US at 1102-05 ("The rule that has emerged ... is that recognition of any private right of action for violating a federal statute must ultimately rest on congressional intent to provide a private remedy."); Thompson, 484 US at 179 (noting that the intent of Congress is the ultimate issue, and that if the intent cannot be inferred from the statute, its structure, or some other source, then courts should not imply a private remedy); California v Sierra Club, 451 US 287, 297 (1981) ("The federal judiciary will not engraft a remedy on a statute, no matter how salutary, that Congress did not intend to provide.").

${ }^{\text {"s }}$ See Thompson, 484 US at 191-92 (Scalia concurring).

': See, for example, Suter $v$ Artist M, 503 US 347, 363-64 (1992) (refusing to find an implied cause of action under the Adoption Assistance and Child Welfare Act); Thompson, 484 US at 187 (refusing to find an implied cause of action under the Parental Kidnapping Prevention Act); Karahalios v National Federation of Federal Employees, 489 US 527, 536 (1989) (refusing to find an implied cause of action under the Civil Service Reform Act of 1978). 
Courts endeavor to avoid finding implied causes of action for several reasons. First, it is extremely difficult to know from the legislative history what Congress "intended." "Second, finding an implied cause of action may violate the constitutional separations of powers. ${ }^{116}$ Related to this, by creating a cause of action, "a court of limited juris-' diction necessarily extends its authority to embrace a dispute that Congress has not assigned it to resolve." ${ }^{117}$

Under such a presumption against finding federal statutes to contain implied causes of action, courts considering municipal preemption suits should have a relatively straightforward decision. None of the cases that this Comment has considered has involved federal statutes that contain evidence of congressional intent to provide an implied cause of action. It is equally unlikely that any future cases will either. For this reason, courts rarely should find that a federal statute confers upon municipalities an implied cause of action.

\section{Canons Requiring a Plain Statement from Congress Before a Federal Preemption of Traditional State Functions}

Several canons of construction require a clear statement of Congress's intent to abrogate state sovereignty before courts will adopt a construction that limits states' rights. ${ }^{118}$ Among those most relevant to

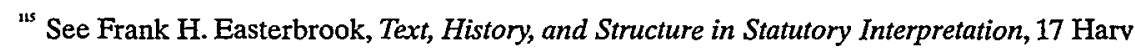
J L \& Pub Pol 61, 68 (1994) ("Intent is elusive for a natural person, fictive for a collective body."); Antonin Scalia, Judicial Deference to Administrative Interpretations of Law, 1989 Duke L J 511, 517 (arguing that "the quest for the 'genuine' legislative intent is probably a wild-goose chase"). Consider also Antonin Scalia, A Matter of Interpretation: Federal Courts and the Law 16-18 (Princeton 1997) (arguing that the search for legislative intent is license for the incorporation of judicial policy preferences in statutory interpretation).

${ }^{14}$ The argument is that implied causes of action are not part of the law upon which there was a bicameral vote by both Houses of Congress, and which was presented to the President for approval. See US Const Art I, $\$ 7, \mathrm{cl} 2$ ("Every Bill which shall have passed the House of Representatives and the Senate, shall, before it becomes a Law, be presented to the President of the United States."). See also Thompson, 484 US at 191-92 (Scalia concurring). When courts find an implied cause of action, they are legislating by creating private causes of action that Congress never addressed. See Conroy v Aniskoff, 507 US 511, 519 (1993) (Scalia concurring in the judgment) ("We are governed by laws, not by the intentions of legislators... The law as it is passed is the will of the majority of both houses, and the only mode in which that will is spoken is the act itself'"), quoting Aldridge v Williams, 44 US (3 How) 9, 24 (1844); Begier v IRS, 496 US 53, 68 (1990) (Scalia concurring in the judgment) ("Congress conveys its directions in the Statutes at Large, not in excerpts from the Congressional Record."); Easterbrook, 17 Harv J L \& Pub Pol at 68-69 (cited in note 114) ("No matter how well we can know the wishes and desires of legislators, the only way the legislature issues binding commands is to embed them in a law."). But see John F. Manning, Textualism as a Nondelegation Doctrine, 97 Colum L Rev 673, 702-05 (1997) (arguing that textualists' contention that the courts' use of legislative history violates Article I's requirements is in tension with other textualist arguments).

"' Cannon v University of Chicago, 441 US 677,746 (1979) (Powell dissenting).

"11 See, for example, Florida Prepaid Postsecondary Education Expense Board v College Savings Bank, 119 S Ct 2199, 2205 (1999) (noting that in order to determine if Congress had abrogated a state's sovereign immunity, a court first must determine if Congress had "unequivocally 
this Comment are the rules against federal preemption or disruption of traditional state functions, ${ }^{119}$ and against congressional expansion of federal court jurisdiction that would siphon cases away from state courts. $^{120}$

Like the canons discussed above, these federalism canons provide legislators with a relatively simple interpretive regime that reduces the ex ante decision costs for those drafting legislation. ${ }^{121}$ More importantly, these canons force legislators to consider the effects their legislation will have on the states. This is particularly important after the Court's decision in Garcia v San Antonio Metro Transit Authority, which left the burden of protecting state sovereignty almost entirely to the political process. ${ }^{123}$ In many ways, federalism can be thought of

expressed its intent to abrogate the immunity"); Seminole Tribe of Florida $v$ Florida, 517 US 44, 55 (1996) ("Congress' intent to abrogate the States' [Eleventh Amendment] immunity from suit must be obvious from 'a clear legislative statement'.") (citation omitted); City of Columbia $v$ Omni Outdoor Advertising, Inc, 499 US 365, 374 (1991) (establishing a presumption against application of federal statutes to state and local political processes); Atascadero State Hospital v Scanlon, 473 US 234, 239-40 (1985) (recognizing a super-strong clear statement rule against congressional abrogation of state Eleventh Amendment immunity from suits in federal courts); Pennhurst State School \& Hospital v Halderman, 451 US 1,25 (1981) (holding that conditions attached to federal funding for state programs must be clear). For a comprehensive list of the canons of construction that protect federalism, as well as the Rehnquist Court's other canons of construction, see Eskridge and Frickey, 108 Harv L Rev at 97-108 (cited in note 109).

${ }^{119}$ See Hawaiian Airlines, Inc $v$ Norris, 512 US 246, 252 (1994) (recognizing that only if Congress manifests a clear purpose will a federal statute be read to supersede a state's historic powers); BFP v Resolution Trust Corp, 511 US 531, 544-45 (1994) (noting that a federal statutory purpose must be "clear and manifest" in order to displace traditional state regulation); Cipollone $v$ Liggett Group, Inc, 505 US 504, 516 (1992) (requiring a clear congressional purpose for federal labeling requirements to preempt state product liability law with regard to cigarettes); Gregory, 501 US at 461-64 (recognizing the authority of a state's citizens to determine the qualifications of their most important government officials).

${ }^{10}$ See Kokkonen v Guardian Life Insurance Co of America, 511 US 375, 377 (1994) ("Federal courts are courts of limited jurisdiction. They possess only that power authorized by Constitution and statute, which is not to be expanded by judicial decree. It is to be presumed that a cause lies outside this limited jurisdiction.") (citations omitted); Finley v United States, 490 US 545, 552-53 (1989) ("Due regard for the rightful independence of state governments ... requires that [federal courts] scrupulously confine their own jurisdiction to the precise limits which the statute has defined.") (citation omitted).

${ }^{221}$ See Eskridge, Dynamic Statutory Interpretation at 276-77 (cited in note 103).

${ }^{12} 469$ US 528, 554 (1985) (holding that applying the wage and hour protections of the Fair Labor Standards Act to state employers exceeded no substantive limitation on the Commerce Clause power).

${ }^{12}$ In justifying its adoption of the clear statement rule, the Supreme Court explained in Gregory v Ashcroft: "[I]nasmuch as this Court in Garcia has left primarily to the political process the protection of the States against intrusive exercises of Congress' Commerce Clause powers, we must be absolutely certain that Congress intended such an exercise." Gregory, 501 US at 464, citing Laurence H. Tribe, American Constitutional Law \$ 6-25 at 480 (Foundation 2d ed 1988) ("[T]o give the state-displacing weight of federal law to mere congressional ambiguity would evade the very procedure for lawmaking on which Garcia relied to protect states' interests."). See also Laurence H. Tribe, Intergovernmental Immunities in Litigation, Taxation, and Regulation: Separation of Powers Issues in Controversies about Federalism, 89 Harv L Rev 682, 695 (1976) ("[T]he courts should not abrogate state immunity unless they are sure that Congress has 
as an underenforced constitutional norm, abandoned in large part by the courts, and rarely considered by federal lawmakers. A canon of construction that requires a clear statement of congressional intent partially cures the systemic failure of Congress adequately to consider federalism, by directly forcing members of Congress to consider and deliberate on legislation that impacts state sovereignty. ${ }^{124}$

Two recent Supreme Court cases explain the scope of these canons. The first is Gregory v Ashcroft, in which the Court found that the control of qualifications for judges is fundamental to state sovereignty. ${ }^{125}$ For this reason, the Court established a clear statement rule to be applied when courts face questions of federalism: "“it is incumbent upon the federal courts to be certain of Congress' intent before finding that federal law overrides' this balance."126

The Court extended Gregory in BFP v Resolution Trust Corp, ${ }^{127}$ which involved an interpretation of the phrase "a reasonably equivalent value" for mortgage foreclosure sales under the federal Bankruptcy Code. Justice Scalia, in the majority opinion, rejected various interpretations of the phrase to mean "fair market value" or "fair foreclosure price," because these interpretations conflicted with the state's laws regulating the foreclosure process. While Justice Scalia conceded that Congress clearly has constitutional authority to regulate bankruptcy, ${ }^{128}$ he was unwilling to interpret the statute in a way that conflicted with state law without a clear statement of Congress's intent to do so. ${ }^{129}$ BFP thus extended the Gregory rule, which involved direct federal regulation of state governments themselves, to federal laws that conflicted with general state regulations. ${ }^{130}$

Gregory and BFP are guides for federal courts deciding whether to grant municipalities a cause of action to sue their states. Similar to Gregory, in which the federal law interfered with state laws governing the structure of its judicial branch, the municipal preemption cases involve federal laws that interfere with the states' ability to structure

considered the federalism interests compromised by suits against states.... [T] he clear statement rule would further ensure that attempts to limit state power were unmistakable, thereby structuring the legislative process to allow the centrifugal forces in Congress the greatest opportunity to protect the states' interests.").

${ }^{12}$ See Eskridge, Dynamic Statutory Interpretation at 286-89 (cited in note 103).

${ }^{13}$ The Court found that this decision "goes beyond an area traditionally regulated by the States; it is a decision of the most fundamental sort for a sovereign entity. Through the structure of its government, and the character of those who exercise government authority, a State defines itself as a sovereign." Gregory, 501 US at 460.

Id, citing Atascadero State Hospital, 473 US at 243.

511 US 531 (1994).

Id at 543, citing US Const Art I, § 8, cl 4: "The Congress shall have Power ... To establish ... uniform Laws on the subject of Bankruptcies throughout the United States."

$B F P, 511$ US at 539-40.

${ }^{100}$ See Eskridge and Frickey, 108 Harv L Rev at 84 (cited in note 109). 
their lower levels of government. After $B F P$, courts must search for a clear statement of congressional intent. Thus, without a clear statement from Congress, courts should exercise prudence and refuse to grant municipalities a cause of action because doing so would come at the expense of state sovereignty.

\section{Other Prudential Reasons to Avoid Hearing These Disputes}

Beyond these canons, there are also practical reasons why federal courts should allow states to maintain their current degree of political control over municipalities. First, although municipalities theoretically are one step closer to the people, these small entities may provide a greater danger to individuals' rights. With their small size and limited fiscal resources, municipalities are more easily captured by large corporations located within their boundaries. ${ }^{131}$ Unlike states, with their larger size and more diverse assortment of employers and taxpayers, small city governments can become dependent on a corporation's presence to provide jobs and taxes for the local economy.

Related to this, excessive deference to local power can make it more difficult for states to remedy racial and financial inequalities among the various municipalities within a state. Often the areas in which people settle are largely predetermined based on their race, class and level of income. Absolute local control of school financing and zoning can heighten the significance of inter-local wealth differences and perpetuate inequalities in education, housing, and employment opportunities. ${ }^{132}$

Finally, courts should consider the consequences of allowing municipalities a cause of action against the state. Allowing causes of action would mean not only that municipalities can sue their state, but also that they can sue other municipalities. Under such a system, the federal courts would be obliged to decide these disputes between local governments. The traditional system, in which the state government oversees its internal affairs as a unified sovereign, works well because the state can resolve local disputes without involving the courts. A rule that allowed municipalities to air their grievances in federal court

\footnotetext{
"See Jonathan R. Macey, Promoting Public-Regarding Legislation through Statutory Interpretation: An Interest Group Model, 86 Colum L Rev 223, 248-49 (1986) (arguing that smaller legislative bodies that represent fewer constituents are more likely to be overtaken by rentseeking special interest groups).

${ }^{10 .}$ Briffault, 90 Colum L Rev at 5-6 (cited in note 79).
} 
would not only be a blow to state sovereignty, but would also entail enormous administrative costs for the courts.

\section{CONCLUSION}

State sovereignty is important to the federal system because states check the abuse of power by the federal government. One of the most important aspects of state sovereignty is each state's freedom to structure its internal political organization without federal interference. A congressional grant of an implied cause of action to municipalities would seriously impede this autonomy. Municipalities that were previously beholden to the state for all their power would suddenly have independent federal power. This would weaken the states' ability to structure their government without fear that their decisions to create municipalities might be used by the federal government as weapons against them. Furthermore, hearing these suits would weaken citizens' perceptions of the state as a viable alternative to a strong federal government.

For these reasons, a convincing argument can be made that Congress does not have the authority to grant municipalities an implied cause of action to sue their states. Admittedly, the extent to which federalism protects states' sovereignty is currently unclear. However, even courts that prefer not to answer such tough questions of federalism should still refuse to allow these cases based on prudence alone. Several well established canons of construction and practical concerns suggest that federal courts should leave it to the state system to resolve such cases. 